ISSN 1810-3030 (Print) 2408-8684 (Online)

Journal of Bangladesh Agricultural University

Journal home page: http://baures.bau.edu.bd/jbau, www.banglajol.info/index.php/JBAU

\title{
Evaluation of pre-harvest interval for pesticides on different vegetables in Bangladesh
}

\author{
$\bowtie$ Md. Touhidul Islam and Md. Anowarul Haque
}

School of Agriculture and Rural Development, Bangladesh Open University, Gazipur- 1705, Bangladesh

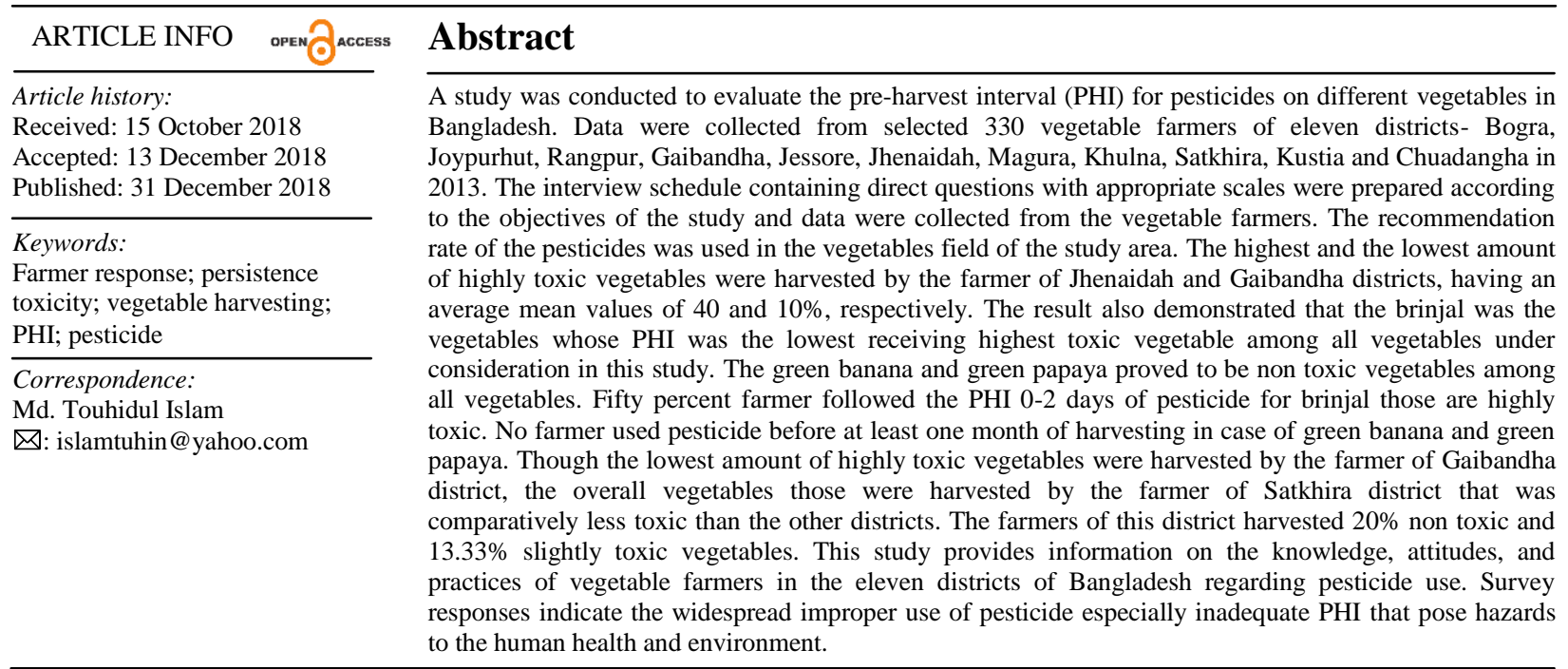

Copyright:

(c) (i)

(C)2018 by authors and BAURES. This work is licensed under the Creative Commons Attribution International License (CC By 4.0).

\section{Introduction}

Bangladesh is predominantly an agricultural country with an area of 147570 sq. km. (BBS, 2016). Agriculture plays an important role in the lives of Bangladeshi people. Vegetables are highly valued in human diet mainly for vitamins and minerals (Hanif et al., 2006). Due to tropical and subtropical climates, variety vegetables are grown in Bangladesh. In 2015-16, cropped area under vegetable crop production was 992000 acres and the total vegetable crop production was 3877000 MT in Bangladesh (BBS, 2016). The farmers of vegetable production in the country do not know the proper doses of the pesticides as well as their toxicity level (Miah et al., 2014). While it is difficult to ascertain the optimum use of these chemicals, it is certainly valid to question the excess use of these chemicals. Environmentalists and nutritionists warn that if the farmers increase the use of chemicals in farming injudiciously food adulteration might be increased tremendously in Bangladesh. Food safety is presently a global concern that is directly related with pesticide residue. The present food safety issues are mainly concerned with food-borne illness, safe use of pesticides and ripening chemicals, and detection and assessment of food adulteration (Van Boxstael et al., 2013). Currently, in Bangladesh, there is public outcry regarding the indiscriminate use of chemicals in vegetables production system (Rahman, 2015). As high-value product value chain is more demanding in food safety and quality standards, greater attention is required for certification and quality enforcement.

Pesticides are the only toxic substances released intentionally into our environment to kill living things (Sarwar, 2015). In the most cases, they are designed to kill pests; however, many pesticides can also pose risks to the peoples (Sarwar, 2015). Chemical pesticides contaminate surface water and as a result, affect fish population, livestock, poultry and human health. To regain the lost status of safe food, it is high time to start agriculture with judicious use of agricultural inputs without further delay. The health effects of pesticides depend on the type of pesticide, some chemicals such as the organophosphates and carbamates; affect the nervous system, while others may irritate the skin or eyes (Sarwar, 2015). There are several classes of pesticide including insecticides (control insect infestations), fungicides (control the spread of fungal diseases), herbicides (control the competing effects of weeds), molluscicides (control the destructive effects of slugs 
and snails) and rodenticides (control the activities of rats and mice) (Aktar et al., 2009; Agrawal et al., 2010). Inappropriate use of pesticides can have negative effects on human health and agro-ecosystems, damage wildlife habitats, create pesticide resistance of insects and diseases, and pollute ground and surface water resources (Recena et al., 2006; Polidoro et al., 2008; Shormar et al., 2014).

Most of the people in Bangladesh are indirect consumers of pesticides through food intake (Prodhan et al., 2018). Due to lack of education, the farmers of our country do not follow the prescribed dosages and use pesticides at any stage of the crop without any awareness of the residues and their ill effects on human health (Prodhan et al., 2018). Every pesticide has a withholding period or pre-harvest interval (PHI), which is defined as the number of days required to lapse, between the date of final pesticide application and harvest, for residues to fall below the tolerance level established for that crop or for a similar food type (Prodhan et al., 2018). The PHI differs from pesticide to pesticide and crop to crop. However, most of the vegetables are supplied from the different districts of northern and southern part of Bangladesh. But very little or limited research work has so far been done to determine how long time the farmer wait for vegetable harvesting after spraying of pesticide. Therefore, the current research work was undertaken to evaluate the pre-harvest interval for pesticides on different vegetables in Bangladesh.

\section{Methodology}

\section{Target areas and population}

The sample selection method was purposive random sampling technique (Tongco, 2007). There were eleven districts in Bangladesh selected purposively as the study area (Table 2). Two to three villages were purposively selected from each district. Vegetables cultivators of these selected villages constituted the population farmers of the study. Thirty farmers were randomly selected from each selected district. Thus a total of 330 farmers constituted the sample farmers for the study (Table 2). List of the vegetables with their local name, scientific name and family those were cultivated by the farmers of this research area that is shown in Table 1.

\section{Data collection}

A questionnaire consisting of structured, semi-structured and unstructured items was designed based on published literature on the subject (Ngowi et al., 2007; Pervin et al., 2018) as well as experiences of the authors in the field. Data was collected through a farm survey by faceto-face interviews with farmers during farming activities. The interview schedule containing direct questions with appropriate scales were prepared according to the objectives of the study. Each of the three draft schedules were pre-tested for necessary corrections, additions and adjustments before going for final data collection. Validity and reliability of some scales were properly determined. Identification and determination of chemical pesticides were done by asking direct questions to the respondents. The questionnaire was designed in English and translated into Bangla, the national language, which is understood by the majority of the farmers and pretested using small samples of farmers in the same areas before using it in this study.

\section{Data analysis}

Data regarding the number of farmer based on the waiting period for vegetable harvesting were collected and divided into four groups, viz. 0-2, 3-7, 8-15 and 1530 days. Then the percentage of farmer based on the vegetable harvesting at different PHI of pesticide was calculated. Depending on the previous literature (Prodhan et al., 2018), the toxicity levels of the vegetables were categorized based on PHI of pesticide as $0-2$ days $=$ highly toxic, $3-7$ days $=$ moderately toxic, $8-14$ days $=$ slightly toxic, $15-30$ days $=$ non toxic. Data were subjected to two factorial (district/vegetable* waiting period, day) analyses of variances (ANOVA-2) without replication followed by Duncan's Multiple Range Test (DMRT) at 5\% level of significance for mean comparison by using SAS software (SAS Institute, 2001).

\section{Results and Discussion}

The respondents of the current study population were 18 to 70 years of age and around $36.37 \%$ of middle-aged (41 to 50) farmers have been involving in vegetable cultivation (Tabulated data were not shown). According to the survey, around $37.27 \%$ of the farmers were illiterate and educational qualification (grade 1 to graduate) of rest of the farmers were $62.72 \%$ (Tabulated data were not shown). A similar phenomenon was observed that the respondents were 21 to 75 years of age and around $38 \%$ of younger farmers were involved in vegetable cultivation. Around $69 \%$ of the farmers had knowledge in medium level (Grade 6 to Advanced level) of education (Sharaniya and Loganathan, 2016).

The results showed significant differences among the districts based on the PHI of pesticide (Table 2). Significant differences were also observed among the vegetables on percentage of farmer based on the PHI of pesticide (Table 3). The highest and the lowest amount of highly toxic vegetables were harvested by the farmer of Jhenaidah and Gaibandha districts, having average mean values of 40 and $10 \%$, respectively (Table 2 ). The result also demonstrates that the brinjal was highly toxic vegetable among all vegetables under consideration in this study (Table 3 ). Fifty percent farmer followed the PHI 0-2 days of pesticide for brinjal those are highly toxic (Table 3). The green banana and papaya proved to be non toxic vegetables among all vegetables under consideration in this study (Table 3). No farmer used pesticide before at least one month of the harvesting in case of green banana and papaya. 
Table 1. List of the vegetables with their local name, scientific name and family cultivated in the study area

\begin{tabular}{llll}
\hline English name & Local name & Scientific name & Family \\
\hline Brinjal & Begoon & Solanum melongena L. & Solanaceae \\
Chili & Morich & Capsicum annuum L. & Solanaceae \\
Tomato & Tomato & Solanum lycopersicum L. & Solanaceae \\
Bean & Deshi shim & Lablab purpureus L. & Leguminoseae \\
Bottle gourd & Lau & Lagenaria siceraria (Molina) Standl. & Cucurbitaceae \\
Cucumber & Shosha & Cucumis sativus L. & Cucurbitaceae \\
Bitter gourd & Korola & Momordica charantia L. & Cucurbitaceae \\
Pointed gourd & Potol & Trichosanthes dioica Roxb. & Cucurbitaceae \\
Ribbed gourd & Jhingga Bandhakopi & Luffa acutangula (L.) Roxb. & Cucurbitaceae \\
Cabbage & Phulkopi & Brassica oleracea var. Capitata L. & Cruciferae \\
Cauliflower & Dherosh & Brassica oleracea var gongyloides L. & Cruciferae \\
Okra & Pepe & Abelomschus esculentus (L.) Moench & Malvaceae \\
Green papaya & Kancha kola & Carica papaya L. & Caricaceae \\
Green banana & & Musa acuminata Colla & Musaceae \\
\hline
\end{tabular}

Table 2. Percentage of farmer among the districts based on the PHI of pesticide

\begin{tabular}{lcccccc}
\hline Name of district & \multicolumn{2}{c}{ Sample size } & \multicolumn{3}{c}{ Percentage of farmer based on the PHI of pesticide } \\
\cline { 2 - 7 } & $\begin{array}{c}\text { Number of } \\
\text { farmer }\end{array}$ & $\begin{array}{c}\text { Area } \\
\text { (decimal) }\end{array}$ & $0-2$ & $3-7$ & $8-14$ & $15-30$ \\
\hline Bogra & 30 & 2310 & 33.33 & 46.67 & 16.67 & 3.33 \\
Joypurhut & 30 & 978 & 16.67 & 60.00 & 23.33 & 0.00 \\
Rangpur & 30 & 1270 & 30.00 & 53.40 & 16.67 & 0.00 \\
Gaibandha & 30 & 1050 & 10.00 & 66.67 & 16.67 & 6.67 \\
Jessore & 30 & 4265 & 36.67 & 36.67 & 10.00 & 3.33 \\
Jhenaidah & 30 & 2240 & 40.00 & 53.33 & 6.67 & 0.00 \\
Magura & 30 & 736 & 26.67 & 50.00 & 16.67 & 6.67 \\
Khulna & 30 & 2153 & 30.00 & 56.67 & 10.00 & 3.33 \\
Satkhira & 30 & 3878 & 13.33 & 53.33 & 13.33 & 20.00 \\
Kustia & 30 & 355 & 30.00 & 46.67 & 20.00 & 3.33 \\
Chuadangha & 30 & 1951 & 23.23 & 53.33 & 20.00 & 3.33 \\
\hline Mean & 30 & 1926 & $26.40 \mathrm{~b}$ & $52.40 \mathrm{~b}$ & $15.50 \mathrm{ab}$ & $4.50 \mathrm{a}$ \\
\hline \multicolumn{7}{r}{} \\
\hline
\end{tabular}

0-2 days $=$ Highly toxic, $3-7$ days $=$ Moderately toxic, $8-14$ days $=$ Slightly toxic, $15-30$ days $=$ Non toxic

Means with the same letter within a row are not significantly different (DMRT-test, $P<0.05$ ).

Table 3. Percentage of farmer among the vegetable based on the PHI of pesticide

\begin{tabular}{|c|c|c|c|c|c|}
\hline \multirow[t]{2}{*}{ Name of vegetable } & \multirow{2}{*}{$\begin{array}{c}\text { Number of } \\
\text { farmer }\end{array}$} & \multicolumn{4}{|c|}{ Percentage of farmer based on the PHI of pesticide } \\
\hline & & $0-2$ & $3-7$ & $8-14$ & $15-30$ \\
\hline Brinjal & 202 & 50.00 & 43.50 & 5.94 & 0.49 \\
\hline Chili & 89 & 25.25 & 48.48 & 10.10 & 10.10 \\
\hline Tomato & 55 & 21.81 & 56.36 & 9.09 & 12.72 \\
\hline Bean & 90 & 42.22 & 53.33 & 4.44 & 0.00 \\
\hline Bottle gourd & 98 & 8.16 & 54.08 & 11.22 & 26.53 \\
\hline Cucumber & 48 & 44.83 & 46.55 & 5.17 & 3.45 \\
\hline Bitter gourd & 93 & 26.88 & 65.59 & 6.45 & 1.08 \\
\hline Pointed gourd & 77 & 27.27 & 57.14 & 14.29 & 1.30 \\
\hline Ribbed gourd & 43 & 46.51 & 44.49 & 0.00 & 9.30 \\
\hline Cabbage & 85 & 17.65 & 67.06 & 9.41 & 5.88 \\
\hline Cauliflower & 79 & 22.78 & 60.80 & 11.39 & 5.06 \\
\hline Okra & 47 & 48.94 & 38.30 & 0.00 & 12.77 \\
\hline Green papaya & 45 & 0.00 & 0.00 & 0.00 & 100.00 \\
\hline Green banana & 41 & 0.00 & 0.00 & 0.00 & 100.00 \\
\hline Mean & 78 & $27.31 \mathrm{~b}$ & $45.41 \mathrm{~b}$ & $6.25 \mathrm{a}$ & $20.62 \mathrm{~b}$ \\
\hline
\end{tabular}

0-2 days $=$ Highly toxic, $3-7$ days $=$ Moderately toxic, $8-14$ days $=$ Slightly toxic, $15-30$ days $=$ Non toxic

Means with the same letter within a row are not significantly different (DMRT-test, $P<0.05$ ).

Our current findings are in match with the results of previous report which revealed that $2 \%$ farmers harvested the product same day of the pesticide application, $3 \%$ of them following day and $55 \%$ of the farmers who had harvest the products after 3-4 days interval. Altogether around $60 \%$ farmers who had harvested the product within seven days from the application of pesticides; but $36 \%$ farmers harvested after one week and around $4 \%$ of them harvested after two weeks (Sharaniya and Loganathan, 2016). 
According to the results of this survey, farmers didn't consider about residual toxicity of pesticides and their health impacts and they considered only their income. This suggesting that the farmers in the study either they do not have clear knowledge regarding residual toxicity of pesticides or they completely ignoring it. Previous research finding also indicates that $8 \%$ farmers applied pesticides prior to exposure of pesticides occur mainly through eating food and drinking water contaminated with pesticides (Davis et al., 1992).

Environmental Protection Agency (EPA) of USA recommended that farmers should allow 1-3 weeks period to reduce the residual effects of pesticides before harvesting the crop and it's depending on the type of pesticides (Sharaniya and Loganathan, 2016). But most of the Bangladeshi farmers do not follow the EPA guidelines. The maximum residual limit (MRL) of pesticides in the vegetables for human is $0.1-0.3 \mathrm{mg} / \mathrm{kg}$ (depending on the type of pesticides and vegetables) that is only possible to get within one week after spraying of pesticides (Prodhan et al., 2018). It indicates that maximum vegetables in Bangladesh cross the MRL. However, though the lowest amount of highly toxic vegetables were harvested by the farmer of Gaibandha district, the overall vegetables those were harvested by the farmer of Satkhira district comparatively less toxic than the other districts. The farmers of this district were harvested $20 \%$ non toxic and $13.33 \%$ slightly toxic vegetables.

\section{Conclusion}

This study provides information on the knowledge, attitudes, and practices of vegetable farmers of eleven districts in northern and southern part of Bangladesh regarding PHI of pesticide. Survey responses indicate the widespread improper use of pesticides especially inadequate PHI of pesticide that pose hazards to the human health and environment. Most of the farmers of our country ignore potential threats to personal health and environmental contamination. Therefore, they appear to be unaware about the extent of pesticide residue levels on local food products or long-term health effects of pesticide residues on consumers. Further research is needed to investigate the amount of the residual toxicity of pesticides on different vegetables in Bangladesh.

\section{Acknowledgements}

The authors are grateful to Bangladesh Open University for providing financial support. The first author completed this research work and prepared the manuscript for their kind cooperation, encouragement and inspiration throughout the period of this study.

\section{References}

Agrawal, A, Pandey, R.S. and Sharma, B. 2010. Water pollution with special reference to pesticide contamination in India. $\mathrm{J}$. Water Res. Prot., 2: 432-448. https://doi.org/10.4236/jwarp.2010.25050
Aktar, M.W., Sengupta, D. and Chowdhury, A. 2009. Impact of pesticides use in agriculture: their benefits and hazards. Interdis. Toxi., 2: 1-12. https://doi.org/10.2478/v10102-009-0001-7

BBS (Bangladesh Bureau of Statistics). 2016. Yearbook of Agricultural Statistics-2016 (28th Series). Statistics and Informatics Division (SID), Ministry of Planning, Government of the People's Republic of Bangladesh.

Davis, J.R., Brownson, R.C. and Garcia, R. 1992. Family pesticide use in the home, garden, orchard, and yard. Arch. Environ. Conta. Toxi., 22: 260-266. https://doi.org/10.1007/BF00212083 PMid:1616309

Hanif, R., Iqbal, Z., Iqbal, M., Hanif, S. and Rasheed, M. 2006. Use of vegetables as nutritional food: role in human health. J. Agric. Biol. Sci., 1: 18-22.

Miah, S.J., Hoque, A., Paul, A. and Rahman, A. 2014. Unsafe use of pesticide and its impact on health of farmers: a case study in Burichong upazila, Bangladesh. Toxi. Food Tech., 8: 5767. https://doi.org/10.9790/2402-08155767

Ngowi, A.V.F., Mbise, T.J., Ijani, A.S.M., London, L. and Ajayi, O.C. 2007. Pesticides use by smallholder farmers in vegetable production in Northern Tanzania. Crop Prot., 26: 16171624. https://doi.org/10.1016/j.cropro.2007.01.008 PMid:18528532 PMCid:PMC2410092

Pervin, S., Chowdhury, A.R., Islam, M.M., Ahmed M.B. and Ara, R. 2018. Present status and problem confrontation of oilseed cultivation in southwest region of Bangladesh. J. Bangladesh Agric. Univ., 16: 198-207. https://doi.org/10.3329/jbau.v16i2.37961

Polidoro B.A., Dahlquist R.M., Castillo L.E., Morra M.J., Somarriba E., Bosque-Perez N.A. 2008. Pesticide application practices, pest knowledge, and cost-benefits of plantain production in the Bribri-Cabecar Indigenous Territories, Costa Rica. Environ. Res., 108: 98-106. https://doi.org/10.1016/j.envres.2008.04.003 PMid:18555986

Prodhan, M.D.H., Akon, M.W., Alam, S.N. 2018. Determination of pre-harvest interval for quinalphos, malathion, diazinon and cypermethrin in major vegetables. J. Environ. Ana. Toxi., 8: 553.

Rahman, K.M.A. 2015. Agrochemical use, environmental and health hazards in Bangladesh. Inter. Res. J. Interdis. Multidis. Stu., 1: 75-79.

Recena M.C.P., Caldas E.D., Pires D.X., Pontes E.R.J.C. 2006. Pesticides exposure in Culturama, Brazil- knowledge, attitudes, and practices. Environ. Res., 102: 230-236. https://doi.org/10.1016/j.envres.2006.01.007 PMid:16497291

Sarwar, M. 2015. The dangers of pesticides associated with public health and preventing of the risks. Int. J. Bioinf. Biomed. Engin., 1: 130-136.

SAS Institute. 2001. SAS/Stat user's guide, Version 8.1. SAS Institute, Cary, North Carolina, USA.

Sharaniya, S. and Loganathan, P. 2016. Pre-harvest interval and pesticide contamination in different vegetables collected from local market of Vavuniya, Sri Lanka. Inter. Res. J., 5: 27-30.

Shormar B., Al-Saad K., Nriagu J. 2014. Mishandling and exposure of farm workers in Qatar to organophosphate pesticides. Environ. Res., 133: 312-320.

https://doi.org/10.1016/j.envres.2014.06.010 PMid:24997273

Tongco, M.D.C. 2007. Purposive sampling as a tool for informant selection, Ethno. Res. Appl., 5: 147-158. https://doi.org/10.17348/era.5.0.147-158

Van Boxstael, S., Habib, I., Jacxsens, L., de Vocht, M., Baert, L., van de Perre, E., Rajkovic, A., Lopez-Galvez, F., Sampers, I., Spanoghe, P. et al. 2013. Food safety issues in fresh produce: bacterial pathogens, viruses and pesticide residues indicated as major concerns by stakeholders in the fresh produce chain. Food Contr., 32: 190-197. https://doi.org/10.1016/j.foodcont.2012.11.038 